\title{
KECERNAAN BAHAN KERING, BAHAN ORGANIK DAN PROTEIN KASAR RANSUM YANG MENGANDUNG TEPUNG LIMBAH IKAN GABUS PASIR (Butis amboinensis) SEBAGAI SUBSTITUSI TEPUNG IKAN PADA BROILER
}

\author{
'Digestibility of Dry Matter, Organic Matter, and Crude Protein The Diet \\ Which Contain of Gabus Pasir (Butis amboinensis) Waste Fish Meal to \\ Substitute Fish Meal In Broiler',
}

\section{Rahmayanti Boangmanalu ${ }^{1}$ Tri Hesti Wahyuni ${ }^{2}$ dan Sayed Umar ${ }^{2}$}

1 Mahasiswa Program Studi Peternakan Fakultas Pertanian Universitas Sumatera Utara,

2 Staf Pengajar Program Studi Peternakan Fakultas Pertanian Universitas Sumatera Utara

\begin{abstract}
This study aimed to determine value of the effect of gabus pasir (Butis amboinensis) waste fish meal on digestibility of dry matter, organic matter, and crude protein. This research was conducted at the Laboratory of Animal Biology, Department of Animal Husbandry, Faculty of Agriculture, University of Sumatra Utara from October to November 2015. The design used a completely randomized design (CRD) with 3 treatments and 6 replications, each replication consisted of 2 broilers. Treatments were consisted of $P O=$ control, $P 1=$ gabus pasir waste meal $5 \%$ and 5\% commercial fish meal, P2 = gabus pasir waste meal 10\%. The result showed the average dry matter digestibility (\%) for the treatments of $P 0, P 1$, and P2 were 76,57, 77,96 and 76,26, respectively. Organic matter digestibility (\%) 77,02, 78,41 and 76,75, respectively. Digestibility of crude protein (\%) 84,52, 85,81 and 83,79, respectively. Statistic analysis showed that the treatment of $P 1$ had high significant $(P<0.05)$ higher than $P 0$ and $P 2$ on the dry matter, organic matter and crude protein digestibility. The conclusion of this research that gabus pasir waste fish meal can be used up to 5\% to subtitute fish meal in broiler chicken diet.
\end{abstract}

Keywords : waste of gabus pasir meal, digestibility, broiler

\begin{abstract}
ABSTRAK
Penelitian ini bertujuan untuk mengetahui nilai kecernaan bahan kering, bahan organik, dan protein kasar ransum yang mengandung limbah tepung ikan gabus pasir. Penelitian ini dilaksanakan di Laboratorium Biologi Ternak, Program Studi Peternakan, Fakultas Pertanian, Universitas Sumatera Utara dari bulan Oktober sampai dengan November 2015. Rancangan yang digunakan rancangan acak lengkap (RAL) dengan 3 perlakuan dan 6 ulangan, setiap ulangan terdiri dari 2 ekor broiler. Perlakuan terdiri atas $\mathrm{P} 0=$ kontrol, $\mathrm{P} 1=$ tepung limbah ikan gabus pasir $5 \%$ dan komersil 5\%, P2= tepung limbah ikan gabus pasir $10 \%$. Hasil penelitan ini menunjukkan rataan kecernaan bahan kering (\%) secara berturut-turut untuk perlakuan P0, P1, dan P2 sebesar ; 76,57, 77,96 dan 76,26. Kecernaan bahan organik ; 77,02, 78,41 dan 76,75. Kecernaan protein kasar ; 84,52, 85,81 dan 83,79. Uji statistik penelitian ini menunjukkan bahwa perlakuan P1 memberikan pengaruh yang nyata $(\mathrm{P}<0.05)$ dibandingkan dengan perlakuan $\mathrm{P} 0$ dan $\mathrm{P} 2$ dalam meningkatkan kecernaan bahan kering, bahan organik dan protein kasar. Kesimpulannya bahwa tepung limbah ikan gabus pasir dapat digunakan sampai dengan 5\% untuk menggantikan tepung ikan dalam ransum broiler.
\end{abstract}

Kata kunci: Tepung Limbah Ikan Gabus Pasir, Kecernaan, Broiler. 


\section{PENDAHULUAN}

Pembangunan peternakan mempunyai peranan penting dalam upaya mencukupi kebutuhan protein hewani masyarakat. Sejalan dengan perkembangan penduduk dan tingginya kebutuhan serta kesadaran akan gizi, serta dengan permintaan akan daging broiler untuk memenuhi kebutuhan protein bagi masyarakat cenderung meningkat. Oleh sebab itu, usaha peternakan broiler merupakan salah satu usaha yang cukup potensial untuk dikembangkan.

Pakan merupakan hal yang sangat penting dalam dunia ternak broiler baik secara intensif maupun semi intensif. Salah satu bahan pakan lokal yang dapat dijadikan sebagai bahan pakan adalah tepung limbah ikan gabus pasir (butis amboinensis). Ikan gabus pasir banyak terdapat didaerah Sumatera Utara khususnya Medan Belawan yang berada di Jalan Gabion, Kec. Medan Belawan bertempat TPI (Tempat Pelelangan Ikan) KUD (Koperasi Unit Desa).

Limbah ikan gabus pasir dapat dijadikan bahan pakan karena mengandung protein yang sangat tinggi dan dapat diolah menjadi tepung untuk menjadi pakan ternak yang bernilai ekonomis dan murah, sehingga dapat digunakan untuk menggantikan tepung komersil yang biasanya digunakan sebagai bahan pakan sumber protein dalam ransum ternak yang biayanya relatif mahal.

Kecernaan suatu bahan pakan merupakan pencerminan dari tinggi rendahnya nilai manfaat dari bahan pakan tersebut. Apabila kecernaannya rendah maka nilai manfaatnya rendah pula sebaliknya apabila kecernaannya tinggi maka nilai manfaatnya tinggi pula. Upaya pemanfaatan limbah ikan gabus pasir akan bernilai guna apabila diketahui nilai kecernaannya.

Pengukuran nilai kecernaan suatu pada dasarnya adalah suatu usaha untuk menentukan jumlah zat yang dapat diserap oleh saluran pencernaan, dengan mengukur jumlah pakan yang dikonsumsi dan jumlah pakan yang dikeluarkan melalui feses. Berdasarkan uraian diatas, penulis berkeinginan melakukan penelitian mengenai kecernaan bahan kering, bahan organik dan protein kasar ransum yang mengandung tepung limbah ikan gabus pasir (butis amboinensis) sebagai substitusi tepung ikan pada broiler. 
Jurnal Peternakan Integratif Vol. 4 No.3 Agustus 2016 : 329-340

\section{BAHAN DAN METODE PENELITIAN}

\section{Lokasi dan Waktu Penelitian}

Penelitian ini dilaksanakan di Laboratorium Biologi Ternak Program Studi Peternakan Fakultas Pertanian Universitas Sumatera Utara. Penelitian ini berlangsung selama 1 bulan dimulai dari bulan Oktober sampai dengan November 2015.

\section{Bahan dan Alat Penelitian}

\section{Bahan}

Bahan yang digunakan yaitu broiler umur 35 hari sebanyak 36 ekor, bahan penyusun ransum terdiri dari jagung, dedak padi, bungkil kelapa, bungkil kedelai, tepung ikan, minyak nabati, tepung limbah ikan gabus pasir (Butis amboinensis); top mix, air minum, air gula, rodalon sebagai desinfektan kandang dan peralatan tempat pakan dan minum, formalin $40 \%$ dan $\mathrm{KMnO}_{4}$ (Kalium Permanganate) untuk fumigasi kandang, vitamin dan suplemen tambahan seperti Vitachick, vaksin ND strain Lasota.

\section{Alat}

Alat yang digunakan adalah kandang model panggung sebanyak 18 plot, masing-masing dengan ukuran panjang $100 \mathrm{~cm}$, lebar $72 \mathrm{~cm}$ dan tinggi $100 \mathrm{~cm}$ peralatan kandang terdiri dari 18 unit tempat pakan dan 18 unit tempat minum dan timbangan salter digital kapasitas $3000 \mathrm{~g}$ untuk menimbang bobot badan ayam dan menimbang ransum, alat penerang dan pemanas berupa lampu pijar 40 watt sebanyak 18 buah, termometer sebagai pengukur suhu kandang. Alat pencatat data seperti buku data, alat tulis dan kalkulator, alat pembersih kandang berupa sapu, ember, sekop dan hand sprayer, alat lain berupa plastik, ember dan pisau.

\section{Metode Penelitian}

Metode penelitian yang digunakan adalah rancangan acak lengkap (RAL) yang terdiri dari 3 perlakuan dan 6 ulangan setiap ulangan terdiri dari 2 ekor broiler. Pada ransum diberikan perlakuan sebagai berikut:

P0 $=$ Kontrol (Ransum dengan tepung limbah ikan gabus pasir sebanyak 0\%)

P1 = Ransum dengan tepung limbah ikan gabus pasir sebanyak 5\% dan tepung ikan komersil 5\% P2 = Ransum dengan tepung limbah ikan gabus pasir sebanyak $10 \%$ 
Model matematik percobaan yang digunakan adalah rancangan acak lengkap

Yij $\quad=\boldsymbol{\mu}+\boldsymbol{\sigma} \mathbf{i}+\sum \mathbf{i j}$

Keterangan :

Yij = Nilai pengamatan yang diperoleh dari satuan percobaan dari perlakuan ke-i dan ulangan ke-j

$\boldsymbol{\mu} \quad=$ Nilai tengah umum

$\boldsymbol{\sigma i}=$ Efek dari perlakuan ke-i

$\sum \mathbf{i j}=$ Pengaruh galat percobaan perlakuan ke-I dan ulangan ke-j (Hanafiah, 2003).

Tabel 1. Susunan Ransum Penelitian Dan Komposisi Zat-Zat Makanan Ransum Penelitian

\begin{tabular}{lccc}
\hline Bahan Pakan & P0 & Perlakuan & \\
& 50 & P1 & P2 \\
\hline Tepung jagung & 10 & 10 & 10 \\
Dedak padi & 7 & 7 & 7 \\
Bungil Kelapa & 10 & 5 & 0 \\
Tepung Ikan & 0 & 5 & 10 \\
Limbah Ikan & 19 & 19 & 19 \\
Bungkil Kedele & 1 & 1 & 1 \\
Top Mix & 3 & 3 & 3 \\
Minyak & 100 & 100 & 100 \\
\hline Total & & & 19.8772 \\
Komposisi Nutrisi & 19.0182 & 19.4477 & 4.3708 \\
\hline Protein Kasar $(\%)$ & 4.3708 & 4.3708 & 5.682 \\
Serat Kasar $(\%)$ & 5.899 & 5.7905 & 3026.1 \\
Lemak Kasar $(\%)$ & 2911.4 & 2968.75 & \\
EM (Kkal/Kg) &
\end{tabular}

Laboratorium Ilmu Nutrisi dan Pakan Ternak (2015)

\section{Parameter Penelitian}

Parameter yang diamati meliputi kecernaan bahan kering, bahan organik dan protein kasar. Perhitungan kecenaan dilakukan dengan menggunakan persamaan dari Schneider dan Flatt (1975) dan Rahjan (1979) dengan rumus sebagai berikut:

Kecernaan $\mathrm{BK}=100-\left\{100 \% \frac{\text { \% lignin dalam ransum }}{\text { \% lignin dalam feces }} \times \frac{\% \text { BK dalam feces }}{\% \text { BK dalam ransum }}\right\}$ 
Kecernaan BO $=100-\left\{100 \% \frac{\% \text { lignin dalam ransum }}{\% \text { lignin dalam feces }} \times \frac{\% \text { BO dalam feces }}{\% \text { BO dalam ransum }}\right\}$

Kecernaan PK $=100-\left\{100 \% \frac{\% \text { lignin dalam ransum }}{\% \text { lignin dalam feces }} \times \frac{\% \text { PK dalam feces }}{\% \text { PK dalam ransum }}\right\}$

Keterangan :

$\mathrm{BK}=$ Bahan kering

$\mathrm{BO}=$ Bahan Organik

$\mathrm{PK}=$ Protein Kasar

\section{Pengambilan Data}

Broiler umur 35 hari dipuasakan selama 24 jam dengan maksud untuk menghilangkan sisa ransum sebelumnya dari pencernaan, koleksi feses didasarkan metode Sklan dan Hurwitz (1980) yang disitir oleh Wiradisastra (1986) dan dimodifikasi oleh Abun (2003). Dalam percobaan ini menggunakan broiler umur 35 hari sebanyak 36 ekor. Setelah broiler dipuasakan, diberi ransum perlakuan masing-masing broiler sebanyak 100 gram dengan pemberian air minum secara ad libitum. Setelah 14 jam, broiler disembelih dan usus besar dikeluarkan untuk mendapatkan sampel feses, feses yang diperoleh kurang lebih $10 \mathrm{~cm}$ dari ileum dengan tujuan untuk menghindari adanya kontaminasi dengan urine kemudian diikat kedua ujungnya dengan benang, sampel feses dikeringkan, digiling dan kemudian dianalisis untuk mengetahui kandungan bahan kering, bahan organik, dan protein kasar, sedangkan indikator internal (lignin) dianalisis dengan metode

\section{HASIL DAN PEMBAHASAN}

Rataan hasil penelitian kecernaan bahan kering, bahan organik dan protein kasar ransum yang mengandung tepung limbah ikan gabus pasir pada broiler selama penelitian.

Tabel 2. Rataan kecernaan bahan kering, bahan organik dan protein kasar selama penelitian (\%)

\begin{tabular}{lccc}
\hline \multirow{2}{*}{ Peubah } & \multicolumn{3}{c}{ Perlakuan } \\
\cline { 2 - 4 } & $\mathrm{P} 0$ & $\mathrm{P} 1$ & $\mathrm{P} 2$ \\
\hline Kecernaan Bahan Kering & $76,57^{\mathrm{b}} \pm 1,15$ & $77,96^{\mathrm{a}} \pm 1,11$ & $76,26^{\mathrm{b}} \pm 1,17$ \\
Kecernaan Bahan Organik & $77,02^{\mathrm{b}} \pm 1,04$ & $78,41^{\mathrm{a}} \pm 1,08$ & $76,75^{\mathrm{b}} \pm 0,63$ \\
Kecernaan Protein Kasar & $84,52^{\mathrm{b}} \pm 0,75$ & $85,81^{\mathrm{a}} \pm 0,72$ & $83,79^{\mathrm{b}} \pm 1,82$ \\
\hline
\end{tabular}

Ket : Huruf a dan $\mathrm{b}$ dengan superskrip yang berbeda menunjukan perbedaan yang nyata $(\mathrm{P}<0.05)$ 


\section{Kecernaan Bahan Kering}

Kecernaan bahan kering diukur untuk mengetahui jumlah zat makanan yang diserap tubuh yang dilakukan melalui analisis dari jumlah bahan kering, baik dalam ransum maupun dalam feses. Selisih jumlah bahan kering yang dikonsumsi dan jumlah yang diekskresikan adalah kecernaan bahan kering (Ranjhan, 1980).

Hasil penelitian kecernaan bahan kering pakan yang mengandung tepung limbah ikan gabus pasir pada broiler dapat dilihat pada Tabel 2 bahwa ratan kecernaan bahan kering ransum tertinggi pada perlakuan P1 (ransum dengan tepung limbah ikan gabus pasir 5\% dan tepung ikan komersil 5\%) sebesar $77,96 \%$. Kemudian diikuti dengan P0 (kontrol) sebesar 76,57\% dan yang terendah pada perlakuan P2 (ransum dengan tepung komersil 10\%) sebesar 76,26\%.

Hasil analisis ragam menunjukkan bahwa penggunaan tepung limbah ikan gabus pasir sampai dengan level 5\% pada ransum memberikan pengaruh yang nyata $(\mathrm{P}<0.05)$ terhadap kecernaan bahan kering. Anggorodi (1994) menjelaskan faktor yang berpengaruh terhadap daya cerna diantaranya bentuk fisik pakan, komposisi ransum dan pengaruh terhadap perbandingan nutrient lainnya. Pada penelitian ini semua perlakuan memiliki bentuk fisik yang sama yaitu halus, akan tetapi komposisi dan perbandingan nutriennya berbeda karena persentase tiap bahan pakan yang digunakan berbeda.

Hasil uji Duncan menunjukkan bahwa nilai kecernaan bahan kering pada perlakuan P1 memberikan pengaruh nyata lebih tinggi bila dibandingkan dengan perlakuan P2 dan P0.. Rataan kecernaan bahan kering sebesar 76,93\% lebih tinggi nilai kecernaannya jika dibandingkan dengan hasil penelitian Siahaan (2015) yang mengukur nilai kecernaan dengan menggunakan tepung limbah ikan gabus pasir sebagai bahan pakan tunggal sebesar 79,29\%. Hal ini terjadi karena penelitian menggunakan ransum yang memiliki nilai serat kasar lebih tinggi dibandingkan dengan bahan pakan tunggal.

Perbedaan nilai kecernaan bahan kering pada setiap perlakuan dengan tertinggi pada P1 diduga disebabkan oleh tingginya konsumsi bahan kering ransum pada perlakuan tersebut dibanding perlakuan P0 dan P2. Bahan kering merupakan cerminan dari besarnya karbohidrat yang terdapat di dalam bahan pakan penyusun ransum, karena sekitar $50-80 \%$ bahan kering tanaman tersusun 
dari karbohidrat. Ranjhan (1980) menjelaskan bahwa tipe kuantitas karbohidrat dalam bahan atau penambahannya dalam ransum mereflesikan daya cerna zat-zat makanan bahan lainnya terutama dengan meningkatnya kandungan serat kasar dalam ransum maka daya cerna zat-zat makanan lainnya akan menurun. Namun, tinggi rendahnya daya cerna zat-zat makanan dalam ransum juga dapat dipengaruhi oleh keseimbangan zat-zat makanan yang terdapat dalam ransum tersebut.

Tilman et al., (1998) juga menjelaskan bahwa kandungan serat kasar dan protein kasar pakan, perlakuan terhadap bahan pakan, faktor spesies ternak serta jumlah pakan akan mempengaruhi kecernaan. Pernyataan ini didukung Anggorodi (1994) yang menyatakan bahwa tinggi rendahnya kecernaan pakan dipengaruhi oleh suhu lingkungan, laju perjalanan pakan melalui alat pencernaan, bentuk fisik bahan pakan, komposisi ransum, dan pengaruh terhadap perbandingan dari zat makanan lain.

\section{Kecernaan Bahan Organik}

Kecernaan bahan organik suatu pakan menunjukkan kualitas dari pakan yang dicerna oleh tubuh. Data Hasil penelitian menunjukkan rataan kecernaan bahan organik ransum yang menggunakan tepung limbah ikan gabus pasir pada broiler dapat dilihat pada Tabel 2 bahwa rataan kecernaan bahan organik tertinggi yang diperoleh dari penelitian dicapai oleh P1 (ransum dengan tepung limbah ikan gabus pasir sebesar 5\% dan tepung komersil 5\%) yaitu 78,41\% dan yang terendah P2 (tepung limbah ikan gabus pasir sebesar 10\%) dengan 76,75\%. Hasil analisis ragam menunjukkan bahwa penggunaan tepung limbah ikan gabus pasir sampai dengan level $5 \%$ pada ransum memberikan pengaruh yang nyata $(\mathrm{P}<0.05)$ terhadap kecernaan bahan organik ransum.

Uji lanjut Duncan menunjukkan bahwa perlakuan P1 memberikan pengaruh nyata lebih tinggi bila dibandingkan dengan perlakuan P2 dan P0. Rendahnya kecernaan bahan organik pada perlakuan P2 disebabkan oleh rendahnya kecernaan bahan kering pada perlakuan tersebut. Hal ini sejalan dengan prinsip perhitungan bahan organik dari analisis proksimat, dimana semakin rendah persentase bahan kering maka akan diikuti pula oleh penurunan persentase bahan organik (Bautrif, 1990). 
Rataan kecernaan bahan organik sebesar 77,39\% lebih rendah nilai kecernaannya jika dibandingkan dengan hasil penelitian Siahaan (2015) yang mengukur nilai kecernaan dengan menggunakan tepung limbah ikan gabus pasir sebagai bahan pakan tunggal sebesar $81,47 \%$. Hal ini disebabkan karena tingginya serat kasar ransum pada setiap perlakuan sebesar 4,37 bila dibandingkan dengan tepung limbah ikan gabus pasir sebesar 2 .

Peningkatan kecernaan bahan kering selalu diiringi dengan meningkatnya kecernaan bahan organik pakan. Hasil penelitian menunjukkan bahwa kecernaan bahan organik yang diperoleh sejalan dengan hasil kecernaan bahan kering. Sutardi (1980) melaporkan bahwa peningkatan kecernaan bahan organik sejalan dengan meningkatnya kecernaan bahan kering, karena sebagian besar komponen bahan kering terdiri atas bahan organik sehingga faktor-faktor yang mempengaruhi tinggi rendahnya kecernaan bahan kering akan berpengaruh juga terhadap tinggi rendahnya bahan organik.

Meningkatnya nilai kecernaaan bahan organik pada setiap perlakuan P0 sebesar 77,02\%, P1 sebesar 78,41\% dan P2 sebesar 76,75\% lebih tinggi bila dibandingkan dengan kecernaan bahan kering disebabkan rendahnya nilai serat kasar pada ransum sebesar 4,37. Sesuai dengan pendapat Tillman et al., (1998) bahwa faktor yang mempengaruhi kecernaan bahan organik adalah kandungan zat nutrisi dalam ransum. Tingginya serat kasar pakan yang tidak dapat tercerna dalam saluran pencernaan menyebabkan nutrisi lain yang dapat dicerna menjadi tidak tercerna dan ikut keluar bersama-sama ekskreta, sehingga menurunkan kecernaan nutrisi lain. Pemberian ransum dengan level serat kasar yang tinggi menyebabkan pemanfaatan nutrien ransum menjadi rendah dan terjadi penurunan bobot badan (Hsu et al., 2000).

Penggunaan serat kasar dalam ransum pada penelitian ini masih dalam batas yang ditentukan dapat dilihat pada Tabel 1 . Hal ini sesuai dengan pernyataan Kartadisastra (1994) bahwa penggunaan maksimum dalam ransum ayam pedaging tidak lebih dari $5 \%$. Jika persentase serat kasar berlebih dalam ransum maka akan menghambat penyerapan zat-zat makanan dalam tubuh ayam. Hal ini sudah diterapkan dalam penelitian sehingga kadar serat kasar dalam ransum hanya berkisar 4,37 . 


\section{Kecernaan Protein Kasar}

Protein merupakan salah satu diantara zat-zat makanan yang mutlak dibutuhkan ternak baik untuk hidup pokok, pertumbuhan dan produksi (Parakkasi, 1999). Data hasil penelitian kecernaan protein kasar ransum yang mengandung tepung ikan gabus pasir pada broiler dapat dilihat pada Tabel 2 bahwa rataan kecernaan protein kasar ransum hasil penelitian untuk perlakuan P0, P1 dan P2 berturut-turut adalah $84,52 \% ; 85,81 \%$ dan $83,79 \%$. Rataan kecernaan protein kasar ransum tertinggi pada perlakuan P1 sebesar $85,81 \%$ dan terendah pada perlakuan $\mathrm{P} 2$ sebesar $83,79 \%$.

Untuk mengetahui pengaruh pemberian tepung limbah ikan gabus pasir terhadap kecernaan protein kasar ransum, maka dilakukan analisis sidik ragam. Hasil uji statistik menunjukkan bahwa penggunaan tepung limbah ikan gabus pasir sampai dengan level $5 \%$ pada ransum memberikan pengaruh yang nyata $(\mathrm{P}<0.05)$ terhadap kecernaan protein kasar ransum.

Penelitian ini diperoleh rataan nilai kecernaan protein kasar ransum sebesar $84,71 \%$. Nilai kisaran tersebut menunjukkan bahwa ransum yang digunakan dalam penelitian ini berkualitas tinggi. Kearl (1982) menyatakan bahwa ada 3 kategori kualitas bahan pakan berdasarkan tingkat daya cernanya, yaitu: nilai kecernaan pada kisaran 50-60\% adalah berkualitas rendah, antara 60$70 \%$ berkualitas sedang dan di atas $70 \%$ berkualitas tinggi. Selain itu, angka kecernaan protein ini masih berada pada kisaran kecernaan protein broiler di daerah tropis yang berkisar 60 - 85\% (Blair et al., 1990).

Hasil uji lanjut Duncan menunjukkan bahwa perlakuan P1 memberikan pengaruh nyata lebih tinggi bila dibandingkan dengan perlakuan $\mathrm{P} 2$ dan $\mathrm{P} 0$. Rataan kecernaan protein kasar sebesar $84,71 \%$ lebih tinggi nilai kecernaannya jika dibandingkan dengan hasil penelitian Jehemat dan Koni (2013) yang mengukur nilai kecernaan dengan menggunakan tepung bekicot pada ayam pedaging sebesar $67,27 \%$. Hal ini disebabkan rendahnya kandungan serat kasar limbah ikan gabus pasir dibandingkan dengan tepung bekicot.

Perbedaan kecernaan protein kasar pada setiap perlakuan dipengaruhi oleh beberapa faktor yaitu kandungan protein bahan pakan, kandungan protein yang masuk dalam saluran pencernaan serta jumlah konsumsi ransum. Menurut 
Maynard et al., (1969) bahwa daya cerna dipengaruhi oleh kandungan zat-zat makanan dalam ransum dan jumlah ransum yang dikonsumsinya. Ranjhan (1980) menambahkan bahwa kecernaan protein kasar tergantung pada kandungan protein di dalam ransum.

Tingginya nilai kecernaan protein kasar ransum pada perlakuan P1 didukung dengan nilai kecernaan bahan organik yang tinggi. Rambet et al., (2016) menerangkan bahwa protein merupakan bagian bahan organik sehingga apabila koefisien cerna bahan organik meningkat maka koefisien cerna protein kasar juga akan meningkat. Pernyataan ini juga didukung Wahyu (1997), bahwa semakin banyak protein yang tercerna dalam ransum yang dapat diserap oleh tubuh, maka koefisien cerna ransum juga semakin meningkat sehingga menunjukkan bahwa ransum tersebut bagus digunakan sebagai pakan ternak.

Kecernaan protein ransum berkaitan erat dengan kecernaan bahan kering ransum dimana nilai kecernaan protein berkaitan erat dengan kecernaan bahan kering ransum, nilai kecernaan protein berbanding lurus dengan kecernaan bahan kering ransum atau sebaliknya (Rambet et al., 2016).

Kecernaan protein kasar tergantung pada kandungan protein dalam ransum. Ransum yang kandungan proteinnya rendah, umumnya mempunyai kecernaan yang rendah pula dan sebaliknya. Tinggi rendahnya kecernaan protein tergantung pada kandungan protein bahan pakan dan banyaknya protein yang masuk dalam saluran pencernaan (Tillman et al., 1998). Guna mencapai daya cerna protein yang optimal, nilai nutrien dari protein harus disesuaikan dengan kebutuhan ayam itu sendiri. Faktor yang mempengaruhi jumlah kebutuhan protein pada ternak ayam yaitu: tingkat protein, temperatur atau suhu lingkungan, usia ternak ayam, kandungan asam amino, dan daya cerna (Sklan dan Hurtwitz, 1980).

\section{KESIMPULAN}

Tepung limbah ikan gabus pasir (Butis amboinensis) dapat menggantikan tepung ikan komersil sebagai campuran didalam pembuatan ransum hingga level $5 \%$ dapat meningkatkan nilai kecernaan bahan kering, bahan organik dan protein kasar pada broiler. 


\section{DAFTAR PUSTAKA}

Abun, Denny.R., dan Nyimas Popy Indriani. 2003. Penentuan kecernaan Ransum Mengandung Ampas Umbi Garut (Maranta arundinaceae LINN) pada Ayam Broiler dengan Metode Pemotongan. Jurnal Bionatura Vol. 593): 227-238.

Anggorodi. 1994. Ilmu Makanan Ternak Umum. PT. Gramedia. Jakarta

Bautrif, E. 1990. Recent Development in Quality Evaluation. Food Policy and Nutrition Division, FAO, Rome.

Blair, G. J, Ensiminger, M. E, dan W. W. Heineniman. 1990. Poultry Meat Feed and Nutrition. $2^{\text {nd }}$ Ed The Ensminger Publishing Company, California.

Hanafiah, K. A., 2003. Rancangan Percobaan. Fakultas Pertanian, Universitas Sriwijaya, Palembang.

Hsu, J.C., L.I. Chen and B. Yu. 2000. Effect of levels of crude fiber on growth performances and intestinal carbohydrase of domestic gosling. AsianAust. J. Anim. Sci. 13 (10) : 1450- 1455.

Jehemat, A dan . T. N. I. Koni. 2013. Tepung Bekicot sebagai Sumber Protein Pengganti Tepung Ikan dalam Ransum Ayam Pedaging. Jurnal Veteriner. Vol. 14 No. 1: 111-117.

Kartadisastra, H, R. 1994. Pengelolaan Pakan Ayam. Kanisius.Yogyakarta.

Kearl. 1982. Nutien Requirement of Ruminant in Developing Countries International Feedstuffs Institute, Utah Arg, Exp. Sta, Logan.

Laboratorium Ilmu Nutrisi dan Pakan Ternak, 2015. Program Studi Peternakan FP USU, Medan.

Maynard, L. A and J. K.Lossly. 1969. Animal Nutrition 6 Ed:McGraw-Hill BookCo,New York.

Parrakasi, A. 1999. Ilmu Nutrisi dan Makanan Ternak Ruminansia. UI Press. Jakarta.

Rambet, V., J.F Umboh., Y. L. R. Tulung., dan Y. H. S. Kowel. 2016. Kecernaan Protein Dan Energi Ransum Broiler Yang Menggunakan Tepung Manggot (Hermetia Illucens) Sebagai Pengganti Tepung Ikan. Jurnal Zootek Vol. 36 No. $1: 13-12$.

Rahjan, S.K. and N.N. Pathak. 1979. Management and Feeding of Buffaloes. Ltd., New Delhi. 
Ranjhan, S.K. 1980. Animal Nutrition In The Tropics. Vikas Publishing Hause P and TLtd., New Delhi.

Schneider, B. H and W. P. Flatt. 1975. The Evaluation of Feeds Through Digestibility Experiments. The University of Georgia Press. Athens.

Siahaan, A. M. S. 2015. Nilai Kecernaan Pakan Dengan Tepung Limbah Ikan Gabus Pasir (Butis Amboinensis) Pada Itik Peking Umur 8 Minggu Dengan Berbagai Teknik Pengolahan. Skripsi. Tesis. Universitas Sumatera Utara, Medan.

Sklan, D dan S. Hurtwitz, 1980. Protein Digestion and Absorption In Young Chick and Turkey, J. Nutrition

Sutardi, T. 1980. Landasan Ilmu Nutrisi Jilid 1. Departemen Ilmu Makanan Ternak. Fakultas Pertanian IPB. Bogor.

Tillman, A. D., H. Hartadi, S. Reksohadiprodjo, S. Prawirokusumo, S. Lepdosoekojo. 1998. Ilmu Makanan Ternak Dasar. Gadjah Mada University Press. Yogyakarta.

Van Soest, P. J. 1979. Nutrition Ekologi of The Ruminant Metabolism Nutritional Strategies. The Celulolytic Fermentation and Chemistry of Forage and Plan Fibers. Cornell University, O \& B Books Inc, Oregon.

Wahyu, J. 1997. Ilmu Nutrisi Unggas. Gadjah Mada University Press. Yogyakarta

Wiradisastra, M. D. H. 1986. Efektifitas Keseimbangan Energi Dan Asam Amino Dan Efisiensi Absorpsi Dalam Menentukan Persyaratan Kecepatan Tumbuh Ayam Broiler. Disertasi, Institute Pertanian Bogor, Bogor. 